\section{ENTEROPATHOGENIC ESCHERICHIA COLI STRAINSFROM DIARRHOEIC STOOLSAMPLES \\ OF CHILDREN BELOW 5 YEARS OF AGE IN DAMATURU, YOBE STATE, NIGERIA}

Deji-Agboola, Anotu Mopelola*; Ali, Mohammed; Osinupebi, Olubunmi Adetokunbo and Makanjuola Stephen Olaosebikan

Department of Medical Microbiology/Parasitology, Olabisi Onabanjo University, Ago-Iwoye, Nigeria Corresponding author: e-mail address: mopelola.agboola@,oouagoiwoye.edu.ng

\section{ABSTRACT}

Enteropathogenic Escherichia coli (EPEC) is an important cause of deaths mostly in infants and young children with diarrhoea worldwide. This study investigated Enteropathogenic Escherichia co / strains in diarrhoeic stool samples of children below 5 years of age in Damaturu, Yobe State, Nigeria. Microscopy, culture and antibiotic susceptibility tests were carried out on stool specimens obtained from children with diarrhoea. All isolated Escherichia coli were investigated for virulence eae and eaf genes of EPEC strains using Polymerase Chain Reaction method. Information on risk factors of diarrhoea was obtained using the questionnaire. Out of 307 children, $154(50.2 \%)$ were male and 153 $(49.8 \%)$ female, majority $107(34.9 \%)$ were 3 years old. A total of $175(57.0 \%)$ Escherichia coli were
isolated, $19(10.9 \%)$ were identified to be enteropathogenic Escherichia coli of these, $17(89.5 \%)$ were atypical (carries eae genes) while only $2(10.5 \%)$ were typical (harbours eaf genes). Multidru resistance was observed in some of the isolates, the EPEC were resistant to Reflacin (47.4\%), Ciprofloxacin (36.8\%), Augmentin (36.8\%), Septrin (36.8\%). The major factor that predispose children to diarrhoea are poor hygiene practices. Escherichia coli was the most prevalent bacterial causing diarrhoea and atypical EPEC is the predominant strain circulating among these children.

KEYWORDS: Diarrhoea, Enteropathogenic Escherichia coli, eae and eaf genes, children

Accepted Date: 7 March 2019

\section{INTRODUCTION}

Diarrhoea has been well documented as the commonest symptom of gastrointestinal infections and the leading cause of death among children less than 5 years of age in developing countries (UNICEF/WHO, 2009; You et al, 2010; Black al., 2010; Onanuga . Diarrhoea is caused by non-infectious agents and infectious pathogens which include bacteria, viruses and protozoa. Escherichia coli is the most frequently isolated bacterial pathogen from cases of diarrhea all over the world (UNICEF/WHO, 2009; Okeke et al., 2012; Al-Gallas et al., 2007; Nweze, 2010). Enteropathogenic Escherichia coli (EPEC) have been identified as the predominant pathotype among the several diarrheagenic $E$. coli infecting children worldwide (Nguyen et al., 2005; Onanuga etal., 2014; Ifeanyi et al., 2015). The diarrheagenic E. coli pathotypes are described based on epidemiologic, clinical features and specific virulence determinants genes associated with the Kaper, 1988; Kaper and Nataro, 2004; Yu et al. 2018). Virulence determinants genes, the eac (intimin) and bfpA (bundle forming pilus) are used foridentifica for identification and division of EPEC into typica and atypical strains (Nataro and Kaper, 1998; Afset et al., 2004; Nguyen et al., 2006). EPEC is a majo diarrheagenic $E$. coli linked with infant diarrhea in the developing world (Kaper and Nataro, 2004 Ochoa et al., 2008). The prevalence of EPEC infection varies with study populations, age, geographic region, socioeconomic characteristic and methods of detection and diagnosis (Ochoa et al., 2008; Ifeanyi et al., 2015; Odetoyin et al., 2016).

Infections with $E$. coli pathotypes are indistinguishable based on clinical findings of diarrhoeal disease caused by them (Nataro an diarrhoea which are often accompanied by fever, vomiting, and dehydration in children (Vilchez et al., 2009). Poor laboratory facilities in most hospitals settings for serological and molecular tests limited the identification and reporting of aetiology of diarrhoea in E. coli and other enteric bacteria thus under-reporting the different pathotypes of diarrhoeagenic E. coli. The few available reports of diarrheagenic $E$. coli in Nigeria are from researches in Fede (One from reser. (Onanuga et al., 2014; West, (Okeke et al., 2012; Odetoyin et al., 2016) and South-East (Nweze, 2010). This study investigated the prevalence of Enteropathogenic Escherichia coli strains in diarrhoeic stool of children below 5 years of age in Damaturu, Yobe State, Nigeria.

\section{MATERIALSAND METHODS}

Study area

The study was carried out in Damaturu, the capital of Yobe State, North-Eastern Nigeria. The state has 17 Local Government Councils, the major ethnic group includes Manga, Fulani, Bolewa, Hausa and Kanuri. The State has 3 Tertiary Health Facilities, 13 Secondary Health Facilities and 517 Public Health Centres, that is, all the Local Government Areas Headquarters have Government runs Hospitals, and Private Clinics that provide services to the population (Historical Documentati Yobe State, Directorate of Information, 2016).

This study was carried out in General Sani Abacha Specialist Hospital Damaturu Km 3, Gujba Road, Specialist Hospital Damaturu Km 3, Gujba Road,
Yobe State, Nigeria. The hospital has 300-bed Yobe State, Nigeria. The hospital has 300-bed
spaces and 11 different wards. The hospital was selected because it has an emergency paediatric ward, children ward, paediatric department, as well as a high population of paediatric patients. The hospital attends to about 1720 children per month out of which at least 282 are diarrhoea cases Form Medical Record Unit of the hospital, 2017).

\section{Ethical approval}

Ethical approval was obtained from the Medical Research Ethics Committee, Ministry of Health, Damaturu, Yobe State, Nigeria (Ref. No. MOH/GEN/474/VOL.1). Permission to use the patients for the study was also obtained from Hospital authority and Clinicians involved. The concept of the study was explained to the Parents/Guardians of the children and informed consent was obtained for the participation of their children in the study.

\section{Study population}

Children less than 5 years with diarrhoea as confirmed by the clinicians, and whose mother or guardians consented and signed the informed consent form to participate in the study were included. Children over 5 years of age and those whose parents or guardians did not consent were excluded.

\section{Collection and processing of stool samples}

Demographic information such as name, sex and age of children, hygiene, socio-economic status and general information on clinical history was obtained from the patients on pre-validated questionnaires. Sterile plastic universal bottles with to the Laboratory and were processed within 4 hours of collection.

The stool samples were examined macroscopically for the presence of blood and mucous, physical characteristics such as appearance, odour, colour and consistency were also noted. The stool samples were inoculated on MacConkey agar (Oxoid, UK) and subcultured Eosin Methylene Blue agar (Oxoid, UK), all incubations were performed $37^{\circ} \mathrm{C}$ for 18 - 24 hours. Isolates were Gram stain the Gram-Negative isolates were identified using Microbact Identification System (12E) Oxoid as described by the Manufacturer. Antibiotic susceptibility tests were performed on all confirmed Escherichia coli using the disc diffusion method (Clinical Laboratory Standards International, 2013).

Identification of enteropathogenic Escherichia coli strains by PCR method

DNA Template was prepared from an overnight culture isolate of $E$. coli on Trypticase Soy agar by suspending three colonies in $200 \mathrm{uL}$ deionised water in Eppendorf tube, vortex briefly. The supernatant was removed, the pellet was resuspended in $200 \mathrm{uL}$ deionised water, boiled at $100^{\circ} \mathrm{C}$ for 10 minutes and centrifuged at $10,000 \mathrm{rpm}$ for 5 minutes. The supernatant was transferred into a sterile Eppendorf tube as the DNA template and 
stored at $-20^{\circ} \mathrm{C}$. The DNA was amplified using the primers used previously by Vidal et al. (2004), these were designated bfp $1 \&$ bfp 2 and eae-F \& eaeR. The bfp primers amplify the $397 \mathrm{bp}$ of the gene that encodes the bundle forming pills also called EPEC adherence factor (EAF), while the eae primers amplify the 492 bp plasmid localized within the locus of enterocyte effacement (LEE) Pathogenicity Island.

\section{PCR}

All the PCR reactions were performed in $20 \mu$ final volume containing $2 \mu \mathrm{l}$ of the template DNA, $4 \mu$ of PCR mix (containing Hot Start Taq polymerase, $1.0 \mathrm{U}, \mathrm{x} 1 \mathrm{PCR}$ buffer $(50 \mathrm{mM} \mathrm{KCl}, 10 \mathrm{mM}$ Tris $-\mathrm{HCl}, \mathrm{pH} 8.3), 0.2 \mathrm{mM}$ of each dNTP and $1.5 \mathrm{mM}$ of $\left.\mathrm{MgCl}_{2}\right), 0.2 \mathrm{uL}$ each of the forward and reverse primers for 10 picomoles each) and an additional $2 \mathrm{uL}$ of $5 \mathrm{mM} \mathrm{MgCl}_{2}$ to give a final concentration of $2 \mathrm{mM}$ plus $11.2 \mathrm{uL}$ of deionised water.

The thermocycling conditions for all the PCRs were as follows: $95^{\circ} \mathrm{C}$ for 2 minutes, $95^{\circ} \mathrm{C}$ for $15 \mathrm{~s}$, $52{ }^{\circ} \mathrm{C}$ for 8 s and 10 s at $72^{\circ} \mathrm{C}$ for 30 cycles, with a final 2 minutes extension, and all the PCRs wer performed in the performed in the Applied Biosystem Thermal Cycler (Applied Biosystem, USA). Amplified samples were evaluated by $1.5 \%$ agarose gel electrophoresis in Tris-borate-EDTA buffer containing $10 \mathrm{mg} / \mathrm{mL}$ of ethidium bromide, visualized with a UV transilluminator.

\section{Data analysis}

Data were analyzed using statistical package for social scientist software, IBM (SPSS) version 5.0 (2016). Regression analysis tests with the level of significance set at $\mathrm{p}$-value $<0.05$. P-value for each of the carriage risk factors was identified to determine the most significant factors.
Results

Out of 307 children, 154 (50.2\%) were male and $153(49.8 \%)$ female, majority 107 (34.9\%) were 25 -36 months old (Table 1). The macroscopic characteristic of stool samples from children wit diarrhoea is presented in Table 2. 219 (71.34\%) of the samples were watery and $257(83.71 \%)$ have observable mucus. The bacteria isolated from the stool samples includes Escherichia coli 175 $(57.0 \%)$, Enterobacter gergoviae $35(11.40 \%)$ Serratia liquefaciens 26 (8.47\%), Acinetobacter Serratia liquefaciens 26 (8.47\%), Acinetobacter iwofii 26 (8.47\%), Salmonella arizonae 18 $(5.86 \%)$, Citrobacter diversus $18(5.86 \%)$ an Citrobacter freundi $9(2.93 \%)$. Out of 175 Escherichia coli isolated only 19 (10.9\%) were identified as enteropathogenic Escherichia coli using the molecular method, of these $17(89.5 \%)$ carries eae genes with the size of $492 \mathrm{bp}$ while only $2(10.5 \%)$ harbours eaf genes with size 397 bp (Figure 1).Enteropathogenic Escherichia coli were classified as typical when they harbour both ece and eaf genes while they are classif when they habours either eae or eaf genes (Alikhani, et al., 2006)

The antibiotic resistance of the bacteria isolate from the stool samples is presented in Table 3 . Escherichia coli 152 (86.7\%), Acinetobacter iwofi 22 (84.6\%), Citrobacter freundii 7 (77.8\%), Enterobacter gergoviae $23(65.7 \%)$ and Citrobacter diversus 7 (50.0\%) were highly resistant to Augmentin also multiple drug resistance was observed in some of the isolates. Besides, the antibiotics suscetibility isolates. Enteropathogenic Eschericha colity of the Enteropathogenic, Escherichia coli showed that they were resistant to Reflacin $9(47.4 \%)$ Ciprofloxacin 7 (36.8\%), Augmentin 7 (36.8\%), Septrin $7(36.8 \%)$ Table 3 . The major pre-disposing factor for diarrhoea among the children is poo hygiene practices (Table 4 )

\begin{tabular}{|c|c|c|c|}
\hline \multirow{2}{*}{$\begin{array}{l}\text { Age } \\
\text { (Month) }\end{array}$} & \multicolumn{2}{|c|}{ Sex } & \multirow{2}{*}{$\begin{array}{l}\text { Total } \\
\text { N (\%) }\end{array}$} \\
\hline & Male n (\%) & Female n $(\%)$ & \\
\hline $0-12$ & $26(16.9)$ & $9(5.8)$ & $35(11.4)$ \\
\hline $13-24$ & $23(14.9)$ & $17(11.1)$ & $40(13.3)$ \\
\hline $25-36$ & $62(40.3)$ & $45(29.4)$ & $107(34.9)$ \\
\hline $37-48$ & $21(13.6)$ & $76(49.7)$ & $97(31.6)$ \\
\hline $49-60$ & $22(14.3)$ & $6(3.9)$ & $28(9.1)$ \\
\hline Total & $154(50.2)$ & $153(49.8)$ & $100(100 \%)$ \\
\hline
\end{tabular}

Table 2: Macroscopic characteristics of stool samples from children with diarrhoea

\begin{tabular}{ll}
\hline Characteristic & $\begin{array}{l}\text { Number } \\
\text { (percentage) }\end{array}$ \\
\hline Texture & \\
Watery & $219(71.34)$ \\
Semi-Solid & $38(12.37)$ \\
Solid & $50(16.29)$ \\
Colour & $184(59.94)$ \\
Brown & $35(11.40)$ \\
Green & $88(28.66)$ \\
Black & \\
Other features & $257(83.71)$ \\
Mucoid & $23(7.49)$ \\
Bloody & \\
\hline
\end{tabular}

Table 3: Antibiotic resistance of $E$. coli and EPEC isolated from children with diarrhoea

\begin{tabular}{lccllllll} 
Antibiotics & A. iwofii & $\begin{array}{l}\text { S. } \\
\text { liquefaciens }\end{array}$ & $\begin{array}{l}\text { S. } \\
\text { arizonae }\end{array}$ & $\begin{array}{l}\text { E. } \\
\text { gergoviae }\end{array}$ & $\begin{array}{l}\text { C. } \\
\text { freundii }\end{array}$ & $\begin{array}{l}\text { C. } \\
\text { diversus }\end{array}$ & E. coli & EPEC \\
\cline { 2 - 8 } OFX $(10 \mu)$ & $8(30.8)$ & $7(26.9)$ & $6(33.3)$ & $14(40.0)$ & $6(66.7)$ & $6(33.3)$ & $47(26.7)$ & $5(26.3)$ \\
PEF $(10 \mu)$ & $14(53.9)$ & $13(50.0)$ & $4(22.2)$ & $25(71.4)$ & $4(44.5$ & $4(22.2)$ & $69(40.0)$ & $9(47.4)$ \\
CPX $(10 \mu)$ & $0(0.0)$ & $5(27.8)$ & $0(0.0)$ & $17(48.6)$ & $1(11.1)$ & $7(38.9)$ & $4(2.23)$ & $7(36.8)$ \\
AU $(30 \mu)$ & $22(84.6)$ & $11(42.4)$ & $5(27.8)$ & $23(65.7)$ & $7(77.8)$ & $9(50.0)$ & $152(86.9)$ & $7(36.8)$ \\
$\mathrm{CN}(10 \mu)$ & $9(34.6)$ & $8(30.7)$ & $7(38.9)$ & $12(34.3)$ & $3(33.3)$ & $3(33.3)$ & $56(32.0)$ & $2(10.5)$ \\
$\mathrm{S}(30 \mu)$ & $0(0.0)$ & $2(7.7)$ & $1(5.6)$ & $4(11.4)$ & $0(0.0)$ & $0(0.0)$ & $2(1.2)$ & $0(0.0)$ \\
$\mathrm{CEP}(10 \mu)$ & $4(15.4)$ & $5(19.2)$ & $0(0.0)$ & $1(2.9)$ & $0(0.0)$ & $0(0.0)$ & $0(0.0)$ & $0(0.0)$ \\
$\mathrm{NA}(30 \mu)$ & $8(30.8)$ & $9(34.6)$ & $6(33.3)$ & $7(20.0)$ & $3(33.3)$ & $0(0.0)$ & $43(24.6)$ & $6(31.6)$ \\
$\mathrm{SXT}(30 \mu)$ & $6(23.1)$ & $10(38.5)$ & $2(11.1)$ & $11(31.4)$ & $5(55.6)$ & $3(16.7)$ & $67(38.3)$ & $7(36.8)$ \\
PN $(30 \mu)$ & $11(42.3)$ & $12(46.2)$ & $7(38.9)$ & $15(42.9)$ & $3(33.3)$ & $6(33.4)$ & $48(27.4)$ & $5(26.3)$ \\
\cline { 2 - 8 } & & & & & & & &
\end{tabular}

Key:

OFX=Tarivid, $\mathrm{PEF}=$ Reflacin, $\mathrm{CPX}=$ Ciproflox acin, $\mathrm{AU}=$ Augmentin, $\mathrm{CN}=$ Gentamycin,

$\mathrm{S}=$ Streptomycin, $\mathrm{CEP}=$ Ceporex, $\mathrm{NA}=$ Nalidix ic Acid, $\mathrm{SX} \mathrm{T}=$ Septrin, $\mathrm{PN}=$ Ampicilin 
TABLE 4: Predisposing factors for diarrhoea in children under five years

\begin{tabular}{|c|c|c|c|c|}
\hline $\mathbf{S} / \mathbf{n}$ & Risk factors & í bÖNÑ் & 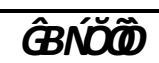 & Övalue \\
\hline \multirow[t]{3}{*}{1.} & Hands washing after remover of diapers & & & \\
\hline & Yes & 118 & 4 & \\
\hline & No & 189 & 171 & 0.042 \\
\hline \multirow[t]{3}{*}{2.} & Hands washing with soaps after toilet & & & \\
\hline & Yes & 63 & 8 & \\
\hline & No & 244 & 167 & 0.036 \\
\hline \multirow[t]{3}{*}{3.} & Hands washing with soaps before serving food & & & \\
\hline & Yes & 4 & 0 & \\
\hline & No & 303 & 175 & 0.047 \\
\hline \multirow[t]{3}{*}{4.} & Hands washing with soaps and water after defecation. & & & \\
\hline & Yes & 29 & 3 & \\
\hline & No & 278 & 172 & 0.011 \\
\hline \multirow[t]{3}{*}{5.} & $\begin{array}{l}\text { Do you use antibiotics whenever your child is } \\
\text { indisposed? }\end{array}$ & & & \\
\hline & Yes & 264 & 167 & \\
\hline & No & 43 & 8 & 0.035 \\
\hline \multirow[t]{3}{*}{6.} & Is the child stooling? & & & \\
\hline & Yes & 307 & 175 & 0.046 \\
\hline & No & 0 & 0 & \\
\hline \multirow[t]{3}{*}{7.} & Does the child experience abdominal pains? & & & \\
\hline & Yes & 179 & 125 & \\
\hline & No & 128 & 50 & 0.028 \\
\hline \multirow[t]{3}{*}{8.} & Does the child have fever? & & & \\
\hline & Yes & 193 & 128 & \\
\hline & No & 128 & 47 & 0.034 \\
\hline \multirow[t]{3}{*}{9.} & Do you maintain long nails? & & & \\
\hline & Yes & 235 & 163 & \\
\hline & No & 72 & 12 & 0.028 \\
\hline \multirow[t]{3}{*}{10.} & Is the child on admission for more than 2 days? & & & \\
\hline & Yes & 273 & 156 & \\
\hline & No & 34 & 19 & 0.061 \\
\hline \multirow[t]{3}{*}{11.} & Does your child experience watery stool? & & & \\
\hline & Yes & 219 & 155 & \\
\hline & No & 88 & 20 & 0.032 \\
\hline \multirow[t]{3}{*}{12.} & Does the child wash hands before eating? & & & \\
\hline & Yes & 92 & 24 & \\
\hline & No & 215 & 151 & 0.031 \\
\hline
\end{tabular}

Fig. 2.0: Geologic Map of Eastern Dahomey Basin (Modified after Billman, 1976).

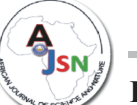

P-ISSN 2536-6904 African Journal of Science \& Nature Vol. 8, 19-27 (2019)

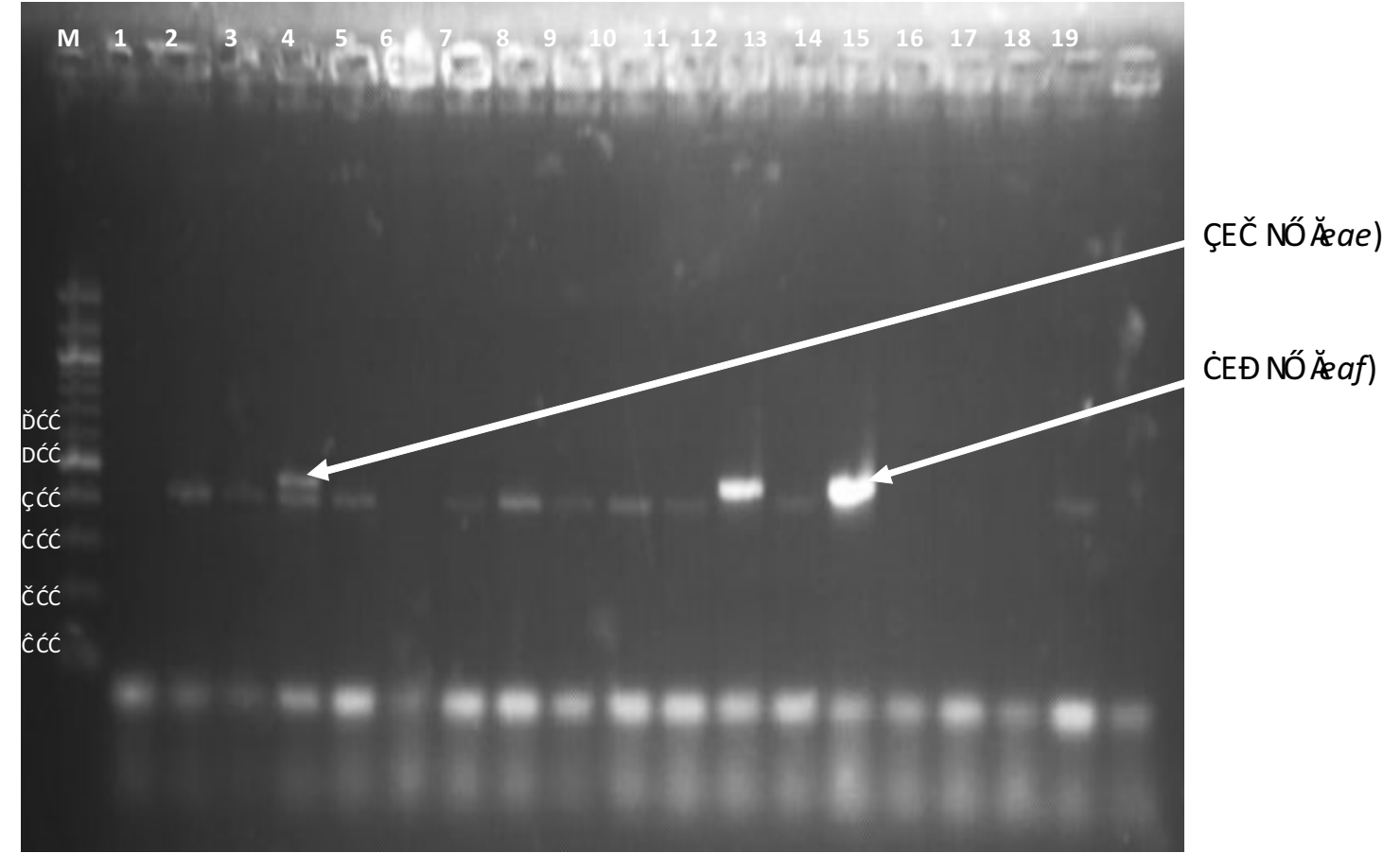

Figure 1: Detection of eae and eaf genes of enteropathogenic E. coil (EPEC) a mong isolated E. coli

Legend: $\mathrm{M}=$ Maker, 1-19 = Enteropathogenic $E$ coli, 492 bp eae genes $=17$ (atypical

Escherichia coli) isolates, $397 \mathrm{bp}$ carrying eaf genes $=2$ (Typical Escherichia coli) isolates

\section{DISCUSSION}

Diarrhoea due to bacterial infection is an important cause of morbidity mortality in infants and young children under the age of 5 years in most developing countries including Nigeria (Adegunloye, 2005). Most of the children diagnosed with diarrhoea in this study were under the age of 3 years. This finding is line with the rof Karambuetal.,(2013).

Majority of the stool samples from the children were mucoid and watery, only few were bloody. Acinetobacter iwofii, Serratia liquefaciens, Salmonella arizonae, Enterobacter gergoviae, Citrobacter freundii, Citrobacter diversus and Escherichia coli were isolated from the stool samples. Okeke et al., (2012) isolated similar bacteria from stool samples of children. Although most of these isolates are normal flora of human,

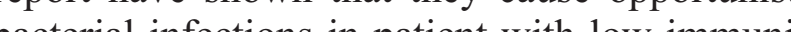
(Kucterial infections in patient with low innunity (Ku et al., 2012). The roles of $A$. iwoffil, C. freundil Salmonella arizonae in gastroenteritis have been reported (Regalado et al., 2013; Mahajan et al., 2003). Escherichia coli $(57.0 \%)$ is the most

prevalence isolate in this study. This high prevalence confirms that Escherichia coli remain the major cause of diarrhoea in children (Yu and Kaper 1992, Onanuga et al., 2014). The result of the antibiotic susceptibility showed that Escherichia coli (86.7\%), Acinetobacter iwofii (84.6\%), Citrobacter freundii (77.8\%), Enterobacter gergoviae $(65.7 \%)$ and Citrobacter diversus

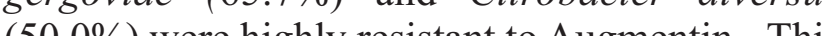
(50.0\%) were highly resistant to Augnentin. This is worrisome because Augmentin is known to possess high level spectrum of antibacterial activity compared to other broad-spectrum antibiotics and may be attributed to inappropriate use, overuse, high prevalence of sub-standard and adulterated drugs in our patent medicine and pharmacy stores. This research work was able to identify the main pre-disposing factor to acquisition of diarrhoea in Damaturu as hand washing and poor hygiene. These were basically observed on the part of the Then were basically ob. washing of hands before serving meas, as well as non-wasing of hands after chancing as well as non-washing of hands after changing of diapers. These factors were also observed by some author (Nguyen et al., 2005; Scaletsky et al., 2010; Lanata 
et al., 2011; Theresa and Carmen, 2012)

The molecular characterization identified $(10.9 \%)$ Escherichia coli to be Entropathogenic Escherichia coli. The identification of eae genes (89.5) indicated that atypical entropathogenic Escherichia coli are the most prevalent Escherichia coli causing diarrhoea in children in Damaturu, Yobe state. This was also observed by Trabulsi et al, (2002), Afset et al. (2003); Scaletsky et al, (2010), Tauschek et al, (2013) in similar studies. This is contrary to findings of Martinez-Medina and (2014) that reported higher prevalence of typical Escherichia coli isolates than atypical species. Studies have significantly associated atypical EPEC with endemic (Scaletsky et al., 1999; Vieira et al., 2001) and outbreaks of diarrhoea (Jenkins et al., 2003). Furthermore, atypical EPEC are more prevalent than typical EPEC in both developing and developed countries also, the duration of diarrhea with atypical EPEC is significantly longer than that caused by other pathogens (Afset et al., 2003; Ochoa et al., 2008).

\section{Conclusion}

Escherichia coli isolates is the most predominant bacteria causing diarrhoea in Damaturu, Yobe State and the most common of the Enteropathogenic strain identified were the atypical type. The bacteria isolates showed very high antibiotic resistance to Augumentin. There is a link between diarrhoea and poor personal hygiene in children under 5 years of age at Damaturu, Yobe state, Nigeria

\section{References}

Afset, J. E., Bergh, K., \& Bevanger, L. (2003). High prevalence of atypical Enteropathogenic Escherichia coli (EPEC) in Norwegian children with diarrhoea. J. Med. Microbiol; 52:1015-1019

Al-Gallas, N., Bahri, O., Bouratbeen, A., BenHaasen, A., \& Ben-Aissa, R. (2007). Etiology of acute diarrhea in children and dults in Tunis, Tunisia, with emphasis on liarrheagenic Escherichia coli: preva phenotyping, and molecular epidemiology. phenotyping, and molecular epicen

Alikhani, M. Y., Mirsalehian, A., \& Aslani, M. M. (2006). Detection of typical and atypical enteropathogenic Escherichia coli (EPEC) in Iranian children with and withou diarrhoea. J. Med. Microbiol; 55:11591163

Black, R. E., Cousens, S., Johnson, H. L., Lawn, J E., Rudan, I. \& Bassani, D. G. (2010).Global, regional, and national causes of child mortality in 2008. A systematic analysis. Lancet, (375):19691987.

Ifeanyi, C. I. C., Ikeneche, N. F., Bassey, E. B., AlGallas, N., Aissa R. B., \& Boudabous, A. (2015). Diarrheagenic Escherichia coli pathotypes isolated from children with diarrhea in the Federal Capital Territory Abuja, Nigeria. Journal of Infection for Developing Countries; 9(2):165-174.

Jenkins, C., Lawson, A. J., Cheasty, T., Willshaw, G. A., Wright, P., Dougan, G., Frankel, G. \& Smith, H. R. (2003). Subtyping intimin genes from enteropathogenic Escherichia coli associated with outbreaks and sporadic coli associs en sporadic cases in the United Kingdom and Eire. Mo
Cell Probes 17:149-156

Kaper, J. B., Nataro, J. P., \& Mobley H. L. T. (2004) Pathogenic Escherichia coli. Nat Re Microbiol, 2, 123-140

Karambu, S., Matiru V., Kiptoo, M. \& Oundo, J. (2013). Characterization and factors associated with diarrhoeal diseases caused by enteric bacterial pathogens among children aged five years and below attending Igembe District Indian Journal of Gastroenterology. 31 (1): 3-12

Ku, S. C., Hsueh, P. R., Yang P.C. \& Luh, K.T (2012). "Clinical and microbiological characteristics of bacteremia caused by Acinetobacter lwoffii.". European Journal of Clinical Microbiology \& Infectious Diseases. 19 (7): 501 - 505

Lanata C. F., Walter M., \& Ochoa, E. (2011) Improving diarrhoea estimates. WHO,http://www.who.int/child adolesce nt health/documents/pdfs/improving diar nt_health/documents/pdfs/improving
rhoea estimates.pdf. 243: 115-122

Martinez-Medina M., \& Garcia-Gil L.J. (2014) Escherichia coli in chronic inflammatory bowel diseases: An update on adheren invasive Escherichia coli pathogenicity. World J Gastrointest Pathophysiol. 5 (3): 213-27.
Nataro, J. P., \& Kaper, J. B. (1998). Diarrheagenic Escherichia coli. Clin. Microbiol. Rev; 11:142-201

Nguyen, R. N., Taylor, L. S., Tauschek, M. \& Robins-Browne, R. M. (2006). Atypical enteropathogenic Escherichia coli infection and prolonged diarrhea in children. Emerg. Infect. Dis; 12:597-603.

Nguyen, T., LeVan, P., Le Huy, C., Gia, K., \& Weintraub, A. (2005). Detection and characterization of diarrheagenic Escherichia coli from young children in Hanoi, Vietnam. J Clin Microbiol 43: 755760.

Nweze, E. (2010). Aetiology of diarrhea and irulence properties of diarrheagenic Escherichia coli among patients and healthy subjects in Southeast Nigeria. $J$ Health Popul Nutr; 28: 245-252.

Ochoa, T. J., Barletta, F., Contreras, C. \&Mercado, E. (2008). New insights into the epidemiology of enteropathogenic Escherichia coli infection. Trans. R. Soc. Trop. Med. Hyg. 102:852-856.

Odetoyin B. W. Hofmann J., Aboderin A. O. \& Okeke I. N. (2016). Diarrhoeagenic Escherichia coli in motherchild Pairs in IleIfe, South Western Nigeria. BMC Infectious Diseases 16:28 DOI 10.1186/s12879-016$1365-\mathrm{x}$

Okeke, I., Ojo, O., Lamikanra, A., \& Kaper, J. (2003). Etiology of acute diarrhea in adults in southwestern, Nigeria. J Clin Microbiol 41:4525-4530.

Okeke I.O, Lamikanra A., Steinrück D., \& Kaper C. (2012). Characterization of Escherichia coli Strains from Cases of Childhood Diarrhea in Provincial Southwestern Nigeria.J Clin Microbiol.38 (1): 7-12.

Onanuga, A. Igbeneghu, O. \& Lamikanra A. (2014). A study of the prevalence of diarrheogenic Escherichia coli in children from Gwagwalada, Federal Capital Territory, Nigeria. The Pan African Medical Journal, 17:146-153

Regalado, N. G., Martin, G. \& Antony, S. J. (2013). Acinetobacter lwoffii: bacteremia associated with acute gastroenteritis. Travel medicine and infectious disease. 7 (5): 316 $-317$.

Ribeiro Junior, J. C., Tamanini, R., Soares B. F., de
Oliveira, A. M., F. de G. Silva, F. F. da Silva, Augusto N. A. \& Beloti, V. (2016). Efficiency of boiling and four other methods for genomic DNA extraction of deteriorating spore-forming bacteria from milk Semina: Ciências Agrárias, Londrina, 37 (5): 3069-3078

Scaletsky I.C.A, Aranda K.R.S, Souza T.B., Silva N.P. (2010). Adherence Factors in Atypical Enteropathogenic Escherichia coli Strains Expressing the Localized Adherence-Like Pattern in HEp-2 Cells. J ClinMicrobiol. 48:302-306.

Scaletsky, I. C., Pedroso, M. Z., Oliva, C. A. Carvalho, R. L., Morais, M. B. \& Fagundes-Neto, U. (1999). A localized adherence-like pattern as a second pattern of adherence of classic enteropathogenic Escherichia coli to HEp-2 cells that is associated with infantile diarrhea. Infect Immun 67: 3410-3415

Tauschek M. Gorrell R. \& Robins-Browne R.M.(2013). Identification of a protein secretory pathway for the secretion of heatlabile enterotoxin by an enterotoxigenicstrain of Escherichia coli. PNAS\& (10): 7066-7071.

Trabulsi, L. R., Keller, R., \& Tardelli Gomes, T. A $(2002)$. Typical and atypical enteropathogenic Escherichia coli. Emerg. Infect. Dis; 8:508-513

UNICEF/WHO, (2009) Diarrhoea: Why children are still dying and what can be done, The United Nations Children's Fund (UNICEF)/World Health Organization (WHO)www.thelancet.com>PIIS0140 6736(09)61798-0

Vidal, R., Vidal, M., Lagos, R., Levine, M. \& Prado, V. (2004). Multiplex PCR for Diagnosis of Enteric Infections Associated with Diarrheagenic Escherichia coli. J Clin Microbiol. 42 (4): 1787-1789.

Vieira, M. A., Andrade, J. R., Trabulsi, L. R., Rosa, A. C., Dias, A. M., Ramos, S. R., Frankel, G. \& Gomes, T. A. (2001). Phenotypic and genotypic characteristics of Escherichia coli strains of non-enteropathogenic $E$. coli (EPEC) serogroups that carry EAE and lack the EPEC adherence factor and Shiga toxin DNA probe sequences. J Infect Dis; 183 , $762-772$ 
Vilchez, S., Reyes, D., Paniagua, M., Bucardo, F., Mollby, R., \& Weintraub, A. (2009). Prevalence of diarrheagenic Escherichia coli in children from Leon, Nicaragua. $J$ Med Microbiol 58: 630-637.

You, D. Wardlaw, T; Salama; P \& Jones, G. (2010). Leaves and trends in under-5 mortality, 1990-2008. Lancet. 375:100-103.

Yu, F., Chen, X., Zheng, S. Han, D., Wang, Y., Wang, R., Wang, B., Chen, Y. (2018). Prevalence and genetic diversity of human diarrhoeagenic Escherichia coli isolates by multi locus sequence typing. International multi locus sequence typing. Internation
Journal of Infectious Diseases; $67: 7-13$

Yu, J., and J. B. Kaper. 1992. Cloning and characterization of the eae gene of enterohaemorrhagic Escherichia coli O157:H7.Mol. Microbiol. 6: 411-417. 